\title{
Alternatives Within Capitalism: Sustainability, Financialization, and the Ambiguity of Contemporary Capitalism
}

\author{
Konstanze Senge (Prof.)*, Simon Dabrowski (M.A.) \\ Institute of Sociology Chair for Economic and Organisational Sociology Martin-Luther-University Halle- \\ Wittenberg Emil-Abderhalden-Straße 26-2706108 Halle (Saale) Germany
}

*Corresponding Author: Konstanze Senge (Prof.), Institute of Sociology Chair for Economic and Organisational Sociology Martin-Luther-University Halle-Wittenberg Emil-Abderhalden-Straße 262706108 Halle (Saale) Germany

\begin{abstract}
Contemporary capitalism has been described as financialized capitalism with increasing shareholder pressure towards financial performance of firms (Davis/Kim 2015; Epstein 2005; Froud et al. 2000; Senge 2015; Windolf 2005; van der Zwan 2014). However, economically and non-economically framed critiques of capitalism and corporate action have revived over the course of the last decade (Boltanski/Chiapello 2006; Beyer 2009). Corporations are increasingly being expected to transform themselves towards taking more responsibility for a sustainable development, often described as an alternative way of economizing. With the rise of socially responsible investing, both, financial and sustainability-related expectations, have become more nested, making corporate sustainability a prism of many of the challenges contemporary capitalism is confronted with. However, the question arises whether capitalist organizations can address these heterogeneous expectations or logics simultaneously without neglecting the other. To address this question, this paper draws on empirical results from 25 qualitative management interviews in nine German stock corporations (DAX30, MDAX) conducted in a current research project granted by the German Research Foundation (DFG). The firms' responses point to the ambiguity of contemporary capitalism, with financialization having a finalizing yet not determining role. In view of these results, we want to show with our paper and presentation that the logic of sustainability appears as an alternative within rather than to capitalism, with a probability of a long-term evolution towards a 'sustainable capitalism' (Thornton/ Ocasio 1999, 2008).
\end{abstract}

Key words: Alternatives of capitalism, sustainability, financialization, ambiguity

\section{INTRODUCTION}

Despite observations of regional differences and varieties of capitalism (Hall/Soskice 2001), contemporary global capitalism has often been described as converging towards one common principle of increasing shareholder pressure concerning the financial performance of firms: a tendency sometimes described as a historical formation of 'financial market capitalism' (Windolf 2005) or, more frequently, as a process of 'financialization' (Davis/Kim 2015; Epstein 2005; Froud et al. 2006; van der Zwan 2014), denoted as"the increasing role of financial motives, financial markets, financial actors and financial institutions in the operation of the domestic and international economies" (Epstein 2005, p. 3). The severe consequences of these processes for (real-) economic as well as non-economic contexts such as households or individual life conduct have frequently been addressed (e.g., van der Zwan 2014).

Yet in view of the undeniable consequences of the increasing importance of the financial market orientation, in the wake of the financial crisis from 2008 onward criticism and critiques of capitalism have revived and reinforced. The legitimacy of perceived typical current economic practices has been called into question from different perspectives and angles, explicitly or implicitly positing alternatives to the current version of capitalism.After being firstly raised in the 1970s (Meadows 1972), the sustainability critique became more influential in the 2000s (Chiapello 2013; Kazmi et al. 2015 ) by questioning the ability of capitalism to ensure the long-term reproducibility of social and natural environments in view of thesocial and ecological impacts of economic practices (e.g., Banerjee 2007). Chiapello (2013) suggests that this critique may be distinct from the artistic (and 
social) critiques Boltanski and Chiapello (2005) observed to have been absorbed by capitalism. Very visible current movements of critique are indeed the movements of corporate responsibility (e.g., Senge 2015) and sustainability (e.g., Hiß 2013; Chiapello 2013; Kazmi et al. 2015), focusing on the role of companies as central actors of capitalism. Many recent empirical investigations of corporate practices labelled as "sustainability" or corporate responsibility" have stressed the tendency of such strategies as being a mere legitimacy façade while securing business as usual (e.g., Lohmann 2009; Banerjee 2007; Fleming/Jones 2013; Cho et al. 2015).

However, the diagnoses on which the critiques of capitalism are based often rely on management literature, anecdotal evidence or the inherent dynamics of public and medial discourseswithout examining capitalist, i.e. organizational and corporate practices empirically or without specifying what "business as usual" actually means.Moreover, some of the empirical investigations of corporate sustainability don't take into account contextual differences on the organizational, field or societal or regional level; in the same way,theydo not reflect the differing manifestations of financialization as a dominant trend of contemporary capitalism(Faust 2011; Kädtler 2011; Pohlmann/Lim 2014). In order to assess whether and in how far there is a chance for critiques of and alternatives to capitalism (such as sustainability) to evolve at all- or at least a chance to change the present form of capitalism, one first needs to know what kind of capitalism - or to put it with Max Weber: what 'spirit of capitalism' (Weber 1989) - one is dealing with.

As already mentioned, the evolving expectations to corporate sustainability (and also corporate responsibility)are one of the key challenges posed to capitalism nowadays. We assume that specific organizational responses to sustainability standards or expectations in general implicitly reflect relevant, often habitualized economic orientations, values, norms and identities informing the economic practices that are mobilized in order to respond to challenges. In order to delineate the (subjective)'spirit of capitalism' one is talking about when talking about alternatives to capitalism, it is useful to start with the organizational problem of how to enact heterogeneous expectations and their correlate institutional logics ${ }^{1}$ - in our case, especially the currently dominant financial logic and the sustainability logic - simultaneously in organizational decision-making, for example concerning strategy or projects, without neglecting the other. We thus assume there may be an incomplementarity concerning these logics which constitute specific organizational problems that in turn require management (or 'solutions').

The questions addressed in this articleare thus as follows: (1) What are thepractices of managing incomplementary institutional logics inside publicly listed companies, and which specific organizational problems do they solve? (2) To which (subjective) spirit of capitalism (Pohlmann/Lim 2014; Pohlmann 2014)do these management practices and the problems they solve refer to? And (3), what is the effect of these practices, interpreted as instantiations of a (subjective) spirit of capitalism, on sustainability?

Our findings emerge from a current research project granted by the German Research Foundation (DFG). It deals with the question of how German stock-holding companies handle, with respect to their decision-making and associated organizational structures, two apparently incomplementary institutional logics: the shareholder value principle or the financial logic on the one hand and the principle of corporate sustainability on the other hand. In total, 25 interviews in 9 companies (DAX and MDAX) were conducted with managers in positions such as sustainability, investor relations, human resources, or management control.

The article starts with some basic theoretical and methodical assumptions, followed by a reconstruction of the forms and arrangements of managing incomplementarity in organizations, representing the contingent solutions to similar problems posed by contemporary capitalistic economic systems. Here, we address question (1).Finally, we discuss our results in order to get some clues concerning the spirit of contemporary capitalism that expresses itself in these practices (question 2 ) and the consequences it produces with respect to (corporate) sustainability (question 3). As our results show, there is indeed a certain tendency towards practices of financialization of sustainability, but by carving out the management arrangements these practices are embedded in, the underlying spirit of capitalism seems to be less clear cut and uniform than is often posited. In view of their

\footnotetext{
${ }^{1}$ In the following, we will use the terms 'institutional logics', 'contextures', 'orientations' and 'references' synonymously.
} 
ambivalent consequences, these management practices under certain conditions bear some potential for an evolution towards a 'sustainable capitalism'.

\section{THEORY}

Institutional theory in the past decades has advanced the perspective on institutional logics as multiple higher-order principles that influence action, i.e.,"the socially constructed, historical patterns of material practices, assumptions, values, beliefs, and rules by which individuals produce and reproduce their material subsistence, organize time and space, and provide meaning to their social reality"(Thornton/Ocasio 2008: 101; Friedland/Alford 1991). Organizations can be regarded as the most typical venues of multiple institutional logics due to their embeddedness in heterogeneous environments which are reflected in the internal structures of organizations (e.g., Luhmann 2011; Kraatz/Block 2008; Friedland/Alford 1991).In order to make the ways of managing heterogeneous logics visible, it is necessary to posit some basic assumptions concerning the operations of organizations. In line with traditional organizational theory, sociological systems theory (Luhmann 2011; Seidl/Becker 2006) views organizations as networks of interlinked (communicated) decisions. Decisions can be regarded as choices among alternatives that communicate their contingency. They intendedly or non-intendedly condensate particular organizational structures such as vertical and horizontal communication channels, positions, procedures or formal or informal rules in general, all of which can serve as premises informing further decisions that again impinge upon structures etc. It can be assumed that organizational, i.e. companies' decisions selectively draw upon institutional logics and that organizational structures are shaped by them (Luhmann 2011; Kraatz/Block 2008).

With the increasing importance of financial markets also for 'real-economic' companies, the relevance of a financial logic for corporate decisions has increased (e.g., Epstein 2005;Krippner 2011; Davis/Kim 2015; van der Zwan 2014; Froud et al. 2006). Similarly, principles of corporate sustainability (and corporate responsibility) have been institutionalized as legitimatory principles for companies (e.g., Senge 2015; Hiss 2013; Chiapello 2013). From the perspective of the financial logic, the economic performance (profitability and 'shareholder value') of social responsibility is uncertain, whereas sustainability views the financial logic as obstructive to achieving long-term regenerative capacity of economic, social and ecological resources (Lafaye/Thévenot 2016; Chiapello 2013; Senge 2007, 2015). Thus, the need to address both logics in organizational decisions may raise questions of their compatibility (Beyer et al. 2007; Beckert 2007) and of incomplementarity, i.e. constellations of at least two institutions hindering the effectiveness of the other (Crouch 2005). This in turn, from the organizational perspective, requires ways of managing multiple logics so as to ensure the 'symbolic' as well as 'material' organizational reproduction within social environments.

Corporations as organizations can be regarded as the central actors of modern capitalism and hence as the central actors of capitalist (self-) reproduction. The conditions of this reproduction, however, have varied over the course of time and according to cultural and regional differences (e.g., Boltanski/Chiapello 2006; Krippner 2011; Streeck 2009). The approach in the tradition of Weber (1989) stresses the autonomy of the economic system based on the generation of norms and values that by habituation and socialization allow its own self-reproduction (Weber 1989; Pohlmann 2014; Pohlmann/Lim 2014). Contrary to this, Boltanski and Chiapello's (2005) famous book on the 'new spirit of capitalism' took another direction when stressing the external sources of capitalist reproduction (such as artistic critique) and the importance of the motivation of personnel (Willmott 2013; Pohlmann 2014). ${ }^{2}$ In order to reconstruct the emergence of a (new) historical formation of capitalism, we follow the approach suggested by Pohlmann (2014; Pohlmann/Lim 2014) that aims to reconstruct the subjective spirit of capitalism ${ }^{3}$. This subjective spirit is reflected in internalized and habitualized ideas, maxims and practices of economic actors (ibid.). We interpret them as the respective arrangements of institutional logics prevailing in economic organizational and individual action at a certain place and time. According to Pohlmann (ibid.), the subjective spirit of capitalism is instantiated in three rationales of capitalist action:economic action, organization and life maxims. We focus (like Pohlmann/Lim 2014: 4), on two of them: (a) economic action and (b) organizational

\footnotetext{
${ }^{2}$ We cannot address this topic adequately here, see instead e.g. DuGay/Morgan 2013; Pohlmann 2014

${ }^{3}$ The subjective spirit can be distinguished from the 'objective' spirit of capitalism constituted by teachings and dogma. Boltanski and Chiapello's (2005) study and others, just like Weber, focused on this objective dimension of the capitalist spirit (Pohlmann 2014).
} 
activities, each characterized by general challenges, thus problems that are to be addressed (or solved) in a historically and geographically specified situation that makes specific action resources and hence solutions to these challengesmore probable than others. The solutions to be reconstructed for the rationale (a) of economic action can then be regarded as an answer to the challenge: "How shall I act in a specific economic setting?", while (b) organizational activities revolve around the question of how to lead the company and employees (Pohlmann/Lim 2014: 4). In our case, both questions can be addressed by the organizational arrangements of institutional logics or contextures (see below) that we reconstructed in our research project.

To summarize, we regard companies as central actors of capitalism responding to multiple institutional logics by virtue of organizational decisions and structures. As an apparently prevalent institutional logic, the financial logic is currently challenged by an evolving sustainability logic which may constitute a general problem of incomplementarity for the organization, creating the need for viable solutions. The institutional logics that shape the organizational solutions can then be interpreted as (momentary) manifestations of a subjective spirit of capitalism.

\section{METHODS}

In order to reconstruct the organizational practices from the empirical material (interviews), the procedure proposed by documentary method (Bohnsack 2003) was used. Documentary method proves to be useful because it aims to make visible the implicit as well as the explicit knowledge structures that generate social practice. The implicit, shared and embodied knowledge acquired in socialization are called conjunctive experiential spaces. On the other hand, the explicit, generalized and commonsense types of knowledge are called communicative experiential spaces. The aim of documentary method is then to make explicit multiple overlapping, especially conjunctive (and communicative) spaces that constitute the modus operandi of social practice. This is why it is commonly used in milieu and group research.

Organizations, however, as formally established networks of formal decisions (Luhmann 2011), more frequently use communicative experiential spaces (such as formal structures, procedures, rules, positions) while conjunctive experiential spaces, informal structures or the individual backgrounds of members, are more in the background, being established and reproduced in relation to formal structures. Institutional logics, made up of both communicative and conjunctive elements, can also be counted among these social spaces. Thus, in organizations, multiple social spaces come together and in the resulting organizational practices have to be processed and arranged (Jansen et al. 2015). The contextural analysis proposed by Jansen et al. (2015), as an advancement of traditional documentary method, allows to relate multiple experiential spaces and perspectives to each other by treating them as logically equal and autonomous contextures, such as stakeholders, hierarchical relations, rules, procedures, markets etc., which are made relevant in the communication about organizational practice (e.g. in interviews). In organizational practice, these contextures have to be processed "with and against each other" (Jansen et al. 2015: 8) to produce what is generally perceived as organization. There are different ways of arranging these contextures. The reconstructed arrangements can then be interpreted as stable arrangements of social spaces or contextures which constitute, in line with functional method (Jansen et al. 2015: 30; Vogd et al. 2018: 33-57), contingent and variable solutions to (analytically reconstructed) reference problems created in the very process of relating these multiple contextures to each other empirically.

Based on these assumptions, the interpretation process was as follows. The institutional logics (financial and sustainability logics or others) and the organizational elements referred to in the process of the interview were identified in the interviews. This means, contrary to Jansen et al., we used assumptions and concepts from organizational and institutional theory (see above) as heuristics and sensitizing concepts to identify the relations of institutional logics and organizational elements, each consisting of various contextures in the sense of Jansen et al. (2015). The interpretation process was thus both deductively and inductively oriented.Through case comparison, arrangements of (or the practices of relating) institutional logics and organizational elements were identified and condensed. Furthermore, the specific organizational problems these arrangements or practices refer to, i.e. are a contingent solution to, were reconstructed. The specific organizational problems can be thought of as empirical manifestations of the theoretical problem of incomplementarity. 


\subsection{Translation I: Financialization of Sustainability}

In the examined companies, sustainability related investment decisions were often portrayed as being aligned with internally available scripts, technologies and procedures which seem to be routinely mobilized for other corporate decisions, namely that of accounting and of management control. One can speak here of a "translation" of sustainability: expectations, standards, models are not adopted undifferentiated from the environment but are transformed according to organizationally available editing rules (Sahlin/Wedlin 2008). Asked about relevant decision criteria for sustainability related projects, the interviewee's answer doesn't leave much room for doubts:

"Interest yield. And then I am back at objectifying the topic. We have to succeed either through ecological topics such as water consumption, electricity consumption or also topics such as satisfied employee runs faster or sponsoring Bayern Munich may gain us more customers.If I cannot translate it into numbers, and those are really simple systems, we also know that capital return barriers for investments are part it and capital consumption and so on, all this is processed very professionally by management control. (...) Only when I can show, that it makes sense, there is a chief representative who takes care of consistent standards, namely those that pay off for the company in many respects, positive image out there, because I can derive this and that from it, lower energy consumption, sustainable hedge of the refueling of fleet through investments in renewable resources, you name it." (Company 1, Investor Relations; own translation)

The internal taken-for-grantedness of practices of calculation becomes very evident in this passage. Sustainability topics are ascribed a precarious status of the "non-factual", "non-objective"; relating them to "interest-yield" ("Verzinsung"), is then presented as a means that makes it possible to regard sustainability a "factual" topic. "Sustainability topics" are supposed to be subjected to internal standards, it should "pay off" - by being measurable, quantifiable and monetizable: Fundamentally different values such as employee satisfaction, energy and water consumption are made comparable and thus relatable (Heintz 2010) along numerically and monetarily constructed parameters that make them commensurable (Espeland/Stevens 1997)in order to "make sense" within the company. Sustainability are thus transformed into decidable issues. Another passage from another company that has a very different tradition of sustainability, being evaluated much differently externally, makes the internal orientations even more clear. A monetary or quantitative metric produces comparability of heterogenous values:

"Well, and then we- in the past few years we really made it- or last year, we really made it, so we can say: We have made an analysis, where is the biggest impact? Of which parameter? Which of them we can really, clearly quantify? And then we have constructed a model, in which we could say: for example, employee satisfaction, increase one per cent. But also decline impacts our gross margin by 35 to 40 millions. Well, we haven't calculated the business case completely yet, so that we could say: How much do we need to invest to achieve one per cent? At the moment we can only say: We can see an impact on gross margin, we have calculated that for employee satisfaction, for our operative health index, and for employee loyalty, concerning the social aspects, and for greenhouse gas emissions we have done the same, then it is one percent up down, it's four millions. We have done that, on the one hand to clearly communicate in the firm, our non-financial aspects, social and environmental, have an influence on our financial performance. And the next step of course is to get out of this tree-hugging and philanthropy corner. I must monetarize it to get management attention."(company 2, Sustainablity, own translation)

The incomplementarity or incompatibility of sustainability and routine economic orientations within the firm is the main problem managers try to address here. The "monetarization" of "non-financial aspetcs" again seems to be the way to get a share of the scarce good of "management attention". Sustainability is portrayed as an economic territory (Miller/Power 2013), in which investments produce certain monetary outcomes. This territory again is framed by categories that could easily be matched with financial market frames, explicitly defined as a "business case". Through commensuration, sustainability aspects as corporate goals become reduced to quantifiable parameters and correlations that can be used to signal a contribution to the financial performance of the firm, also vis a vis external audiences. Internally, they are already in formats usable in communications with the environment (Thévenot 2007). Using standardized Key Performance Indicators (KPIs) makes this external reference easily: 
„Well, basically we took our seven KPIs, and we said: In how far measurable are they? So, are they defined clearly? Are the measurable? And how big ist he effort to get a correlation right?(...) I mean forthe Employee Engagement Index as well as forthat Business Health Culture Index, weget both of them from our annual employee survey. Employee Retention you can get very easily from our HR system: How many people want to leave actually and how many people have I retained? Well, then we have two or three more KPIs. Women in executive positions. We have a very clear goal. But it isit is defined very clearly. It's also easily to determine. But the effort to get a correlation between women in executive position and margin or topline, that's simply a matter of belief."(Company 2 , Sustainability; own translation)

Managerial practice in this company is orientated towards producing correlations between sustainability aspects and the firm's financial performance, represented in the "marge or top line". However, what is more interesting here, is that these correlations are marked as "simply" being "a matter of belief": doubts concerning the validity and objectivity of numbers or calculations - a feature conventionally ascribed to numbers (Porter 1996) - are actively being suspended by the interviewee for the sake of their functionality of providing orientation as a "goal" within the firm. Through commensuration, and thus by mobilizing formally established technologies, managers attempt to address both the formal and informal precarious status of sustainability (and the management positions associated with it) within the firm. In this sense, it serves the internal legitimation of sustainability both as an economically and specifically financially relevant issue as well as in the social relations between managers within the firm. At the same time, commensuration fulfils the function of providing orientation for decisions by making sustainability a decidable topic.

Furthermore, most of the respondents use a language and categories that are, in format and semantic, shaped by financial markets, and that are understood by the respective actors. Additional to its internal function, the translation of sustainability along criteria pertaining to financial markets also serves external functions. An important role here is played by the Dow Jones Sustainability Index (DJSI). In one company, pressure for investment decisions concerning sustainability can be created especially with reference to the requirements of the DJSI. Managers project expectations onto this index, hence expectations of expectations; he thereby constructs the DJSI as an (imagined) audience relevant to decisions, synthesizing and representing financial market observations and expectations (Werron2014). The DJSI's "questions" need to be addressed, and communicating this need seems to create a "momentum" for sustainability related decisions of the board:

"One momentum or- the consciousness to be willing to act for this topic [sustainability] at management level I can trigger only if I have concrete threat scenarios or differentiation scenarios at hand. At the moment, threat scenarios work better, and this means in concreto threat scenarios: ISOstandards. When there is something on the way. That World Business Council for Sustainable Development developed the Natural Capital Protocol, they are about to develop Social Matrix, one time those will be made standards, and then- or the Dow Jones Sustainability Index is getting more and more concrete with its questions. I have to confront them with such things that the management says: Oh, I have to do something. And most of the time that is from the "risk corner", and I am still thinking: gosh, that's it. Let's go a bit further and see how we can enhance value." (Company 5, Sustainability; own translation)

By stressing the „threat"and the "risk" that the DJSI standards seem to pose to his company, the manager emphasizes the internal relevance of external legitimation or at least the signaling of activity of his company concerning sustainability standards. Constructing future economically framed "scenarios" becomes the trigger for decisions or at least for "the consciousness to be willing to act". The observation of being observed thus creates the pressure to implement selective, externally determined aspects in a contemporary and short-term reactivity (Sauder/Espeland 2007). At the same time, in the coda of this passage, the manager marks a difference between his role to create "threat scenarios" and his personal values that make him want to "look how to go a step further". Another manager in the same company stresses the relevance of external audiences by focusing on the perception of being observed by investors, becoming the trigger for the "ambitions" of the firm;

${ }^{4}$ We will address the role of personal values more detailed in the section about personalization. 
internal operations seem to be guided by the informational needs and short-term temporal horizons of the financial markets:

„A positive ranking in the Dow Jones Sustainability Index or the Carbon Disclosure Project is not a value in itself for us, to say: Oh wow, we have a trophy at our fireplace. But it is the insight that many actors, especially at the financial market, don't have the time to pay attention extensively to each company. Many of them depend on several standards, for example from the Carbon Disclosure Project where companies are rated consistently in order to signify: Okay, which companies are the best according to the criteria? (...) And that's why it'sfair enough that [company 5] participates too and faces the ranking. Naturally with the ambition to perform well."(Company 5, Human Resources; own translation)

To sum up, in corporate decisions sustainability is translated according to a monetary metric providing commensurability of formerly different values making visible the "impact" of sustainability on financial performance of the firm (Espeland/Stevens 1998). In this sense, one can speak of a financialization of sustainability ( $\mathrm{Hi} \beta$ 2013): standardized and formalized financial calculation technologies and parameters are used in order to evaluate the objects of investment decisions (Chiapello 2015). Internally, commensuration serves to orientate and to legitimize sustainability; by embracing central figures of (financial) narratives (Haack et al. 2012) such as the "business case" attention and connectivity for further sustainability topics can be created within the firm. At the same time, financializing commensurations such as KPIs are useful for external communication with financial markets, often represented within the firm as a "universalized third" (DJSI) and its requirements, serving as mirrors (White 1981) in which firms can observes themselves and their competitors (Werron 2014). Firms also, by virtue of their disclosure activities feeding the informational needs of "the" financial market with dense and compact signals. They are part of the attentional regime of the financial market (Knorr-Cetina 2012), and thus co-produce financial them. Supplementary to its internal coordination function, financializing sustainability also serves to signal activity to financial markets and to produce decision criteria for investors, as Hiß (2013) has shown similarly for financial analysts.

Financializing commensuration serves to mediate between the financial and the sustainability logics. The organizational problem financialization refers to is the uncertainty sustainability standards still seem to produce within the firm: This uncertainty is founded in the incomplementarity or incompatibility produced by sustainability standards (represented in by the respective management positions)and organizational routines shaped by economic and financial orientations. Financialization in its internal and external forms then serves as a solution and resource for managerial action for orientation and legitimation. The effects of this are ambivalent:Commensuration produces selectivity in what corporate social and ecological issues and activities are attended to or not, and in which form - it makes certain aspects visible, yet others invisible and thus unobservable and irrelevant for organizational decisions (e.g. Espeland/Stevens 1998; Porter 1996). Complex issues, like employee satisfaction, were reduced to measurable and reportable variables (Senge 2015; Mackenzie 2009; Lohmann 2009), such as days of sick leave. Only those sustainability activities that could be proven to have a substantial impact on the financial and economic performance of the corporations was attended to and pursued in terms of decided projects. Organizations develop certain 'forms of inattentiveness' that may become premises for further decisions, and that may stabilize blindness with respect to certain issues (Knudsen 2011). On the other hand, only by selectivity and reduction, issues of sustainability could enter the companies in a viable fashion so as to create connectivity for further activities and decisions; more fundamentally, only by financialization or more specifically financializing commensuration, sustainability just became visible and a territory for economic action.Miller and Power (2013) speak of the 'territorializing role' of accounting technologies. Financial goals thus always accompany investment decisions and their internal and external legitimization.

\subsection{Translation II: The Management of Ambiguity and the Limits to Financialization}

However, as is shown subsequently, these financialized goals do not determine what happens operationally in sustainability projects. Financial contextures or logics always need to be related to other contextures which condition each other; financial translations thus are not the solution for any problem within the firm but need to be regarded in an arrangement with other translations 
(Sahlin/Wedlin 2008); the form of these translations varies from firm to firm while they refer to a similar problem.

In organizational decision making, and especially in operational units, other contextures than the financial logic need to be taken into account.Financialization is then conditioned and moderated by these other logics or contextures, respectively.As will be shown, this depends highly on the internal construction of relevant environments, their enactment (Weick 1995); such enacted environments make a difference in the translation of sustainability in the firm, and hence also impact on the respective internal relevance of the financial market logic. As such, these environments carry different requirements into organizational decision processes which can also be addressed differently by operational units. In this case, for example product markets represent different "realities" within the firm that need to be taken into account:

„We have various business units. All of them have different customer structures and consume different quantities of these minerals. And now it can happen: The customers' pressure concerning reporting and transparency about conflict minerals in one business unit is extremely high. In another business unit it almost doesn't exist yet. (...) That means, when we talk about the speed of implementation, one says, I don't understand, why should I care? And the other one says: If we don't care about it now, I take a risk! (..) And these are controversies. These are no contradictions, but it's possible that the realities are different.But we have to join them again in the company, raise them to one level again, and then we really have to consider: what is the smallest common denominator? What is the greatest common factor?"(Company 9, Investor Relations; own translation)

There are different "realities" and" speeds" concerning the implementation of corporate sustainability measures within the business units of the firm; this is attributed to the different "customer pressures" of product market environments. However, these realities are also said to be in need to be managed again, hence requiring a more complex solution at the organizational level. For "transparency" and reporting to be implemented, the expectations of different product market clients are crucial - even in comparison to financial market pressure:

IR: If a supplier - sorry, an important customers says: I will raise my minimum criteria concerning, I don't know, human rights to a new level. And says, If you don't address that, you are out.

SUS: Do it or you are out.

IR (...)Exactly, with the capital market it's easier to handle.There are more nuances, they work less with these assessments, less with minimum criteria, sometimes they ask, do you have a policy, yes, no And then it's about: how do dou do that? What is the management approach? Well, there is more room to manoeuver.

SUS: How do you track it, do you publish it? There are various nuances.

IR: With what KPIs, you have more freedom of portrayal here.Well, of course you have to prove these steps and show: I have a complete process, from the subject to the KPI, but with customers it's more or less black and white. Do you have it or not? (Company 9, Investor Relations (IR) and Sustainability (SUS); own translation)

The "customers" pressure" in company 9 is perceived much sharper and unambiguous than the pressure from financial markets. This is especially striking as the functioning of customers' pressure is portrayed here in an either-or-logic, materialized in customers' questionnaires: either "pressure" is given way or the company is "out. The interaction with these environments then is more in a way of a technical, problem-solving rationality. The stability of relations to customers is more dominant, leaving not much alternatives of action. Meanwhile financial market expectations are viewed in a much less obligatory and determining way with "freedom of portrayal" and "room to maneuver", allowing a more 'symbolic' management of financial market expectations.

In another company, financial market and 'real' economic or other societal orientations are related to each to other in a different way. The importance of serving the communicative requirements of the financial markets is emphasized in a different, more forced way. When describing a product classification, he first describes it by concepts that are (among others) explicitly compatible with the financial market; at the same time, he introduces a second contexture: 
„Another aspect to steer sustainability, that's [product classification], assigning each of our products to one category according to sustainability contribution. (...) We also do that for our portfolio. And then the question of course is: Is more sustainable more profitable in the classic sense? We have checked that for our portfolio and evaluated with forward looking numbers, to say: Okay, is it right can I generate more money with a product that is more sustainable than the competing product, does it have a stronger growth and as a rule of thumb for the whole [company 5] we can say, there is a much stronger growth for more sustainable products. Of course it makes sense. Products that obviously bear a risk of cancer which are [medium sustainability contribution] or [low sustainability constribution], nobody wants them in the market sooner or later. That's the way it is. (Company 5, Sustainability; own translation)

The product classification is described as part of the company's "portfolio" to which it should contribute; it is utilized for the company's self-presentation within capital market communications represented in the phrase of whether it "more sustainable more profitable" and "forward looking numbers", opening upa comparative horizon of competitors. Risk of cancer is seen as a market opportunity, projectively yielding more "growth". In addition to this, he establishes product markets and the expectations of customers as a second reference. This is elaborated a bit later:

„The market is crucial, of course our customers demand conventional products that do not have a high sustainability contribution. And it would be utopic to assume that [company 5] only brings [high sustainability contribution] products to the market. Since the reality simply us: it's always a mix. (...) So, we take responsibility to bring more sustainable products to the market but we also observe that customers partly demand conventional solutions. But as soon as, I am thinking of the critical public, if the latter put pressure on our customers that would change radically overnight." (Company 5, Sustainability; own translation)

The different requirements of "the market" need to be taken into account, in fact, they are "decisive". At the same time the company is supposed to react flexibly to sudden chances in this environment, represented in the "critical public". This is yet another contexture brought in here as relevant: "the critical public" and the customers' relations to it make a difference for the company's product "portfolio". A possibility to at least temporarily integrate the heterogeneous expectations of different customers, the critical public and probably the financial markets is provided by the company's selfdeveloped five-tier product-classification, serving as a kind of compromise object: by its ambiguity, it can contribute to the company's portfolio vis a vis customers and investors and thus to the public presentation of the company's strategy; the relationship to very different customers can be maintained while enabling the company to react somewhat flexibly to sudden changes in a complex environment (customers-critical public); and, not least, it is possible for the company to signal future commitment to sustainability vis a vis the "critical public" - without dismissing continuing attachments to customers with more conventional demands. In this sense, the company's product classification is a 'boundary object' (Bowker/Star 1999), allowing to mediate between different requirements without conflating these identities. In another project of the same company, this is practiced in a similar way. The "shared value" strived for in an irrigation project in Africa is stressed - which is to be accomplished by the project's "market-based approach" enabling the company to "carry" one of its product segments "into developing countries". At the same time „our product was mentioned very often in integrated reporting. We have always scored in the Dow Jones Sustainability Index.We are an important innovation driver because we are exposed to the needs of a huge number of humans, of which only a few in this company have ever heard of. It's a big share of mankind which is potentially interesting for other solutions of our company or for our innovations, because not everyone who is poor now will be poor tomorrow. (...) And even low buying power can accumulate and when there is a cost-effective solution that is affordable and available, others will follow. "(Company 5, Business unit; own translation)

First, a reference to the financial markets is made again by attributing the company the role of an "innovation driver" and by virtue of that, bringing in "scores" at the DJSI. Simultaneously, however,persons in "developing countries", indeed "large parts of humanity", are addressed by this project: as potential, economically acting customers, and as aspiring cooperators of the company's innovation strategy with potential upward mobility. Further beneficiaries such as future employees are mentioned in the same passage. The rationale behind, again, seems to be a win-win-calculus as it is 
represented in the concept of the "shared value" the project claims to produce. Again, the project, explicitly framed as market-based with economically constructed actors pursuing particular interests, is a boundary object, allowing heterogeneous interests to participate, and even to be generated in the first place.This 'liberal mode' of coordination is indeed no exception (e.g., Cheyns 2011). The financial market orientation is repeatedly and routinely invoked as an important frame of reference of action. However, this is only in relation to other orientations or contextures that need to be taken into account operationally.

How much such an insufficient action orientation of the financial market logic is a problem prompting reflection and solutions in the same company, can be seen in the following passage, where the translatability between numbers directed at (the self-presentation at) financial markets on the one, and internally used numbers used for technical and sustainability purposes on the other hand is problematized:

[Company 5] has set herself a goal concerning environmental impact. (...) For me, it's crucial that if I commit a goal at the corporate level it is well manageable if I can break it down to the product level. And currently, for me there is a problem between what corporate footprinting in the sense of the triple bottom line performs at the corporate level and in how far the same logic is applicable at the product level (...) Yes, I think the methods that are applied to create the triple bottom line for the corporation, to show the corporate footprint, are mostly based on economic elements. They are approximate values,encryption processes, scientifically accepted. But I cannot steer products that way. At the product level I use an impact pathfinder logic which I cannot use at the corporate level.(..) So, we are very good in lifecycle inventories. Lifecyle, that is, that we can make it for our products and show, if necessary, the improvement for the customers if he uses our product in his process compared to the competing product. (...) I am able to show this at the product level. But I couldn't track it in the triple bottom line.(Company 5, Sustainability; own translation)

What is problematized here is the structural link between organizational units. Steering sustainability in the sense of a triple bottom line, representing communicated and committed corporate goals is not (yet) possible in the way it is promised and expected. There is a hard distinction between the "corporate level", which is attributed responsibility for communication with the financial market but also other stakeholders through goal commitment and the "product level", referring to technical and market-related processes. Both operate according to different "logics", pose different requirements and use different formats directed at different audiences. The problem the manager refers to here again is the insufficiency of single logics, such as the financial market logic, to provide orientation for decisions and action in heterogeneous organizational contexts while still, as a manager and representative of his/her company, having to refer to the company as a unit vis a vis third parties - not only in an interview situation. The financial logic suggests that the company be represented and steered adequately in usable numbers but it is the same logic whose concepts (such as the triple bottom line) pose problems of translatability between different contexts, requiring more ambiguous solutions such as the boundary objects of projects or the product classification that are viable in different contexts.

From this closer look at the operational level of companies we can receive a more adequate picture of which problems financialization of sustainability may be solution for and for which it is not. Financialization of sustainability in the sense detailed above seems to serve as a bracket of the respective companies' sustainability activities, especially at the input and output boundaries, hence in the organizational management of 'institutional' environments (Thompson 1967), such as financial markets. Financial markets and always are taken into account as important environments whose informational 'needs' have to be satisfied at least in the sense of signaling and substantiating (reporting) organizational activity in issues currently in the attentional focus of investors. In this sense financialialization of sustainability has a legitimatory function vis a vis internal and external audiences. Furthermore, by its selectivity, it fulfills an orientational function for decisions, setting the frame of what is possible next and what is not possible (see above).

However, operationally in further sustainability activities, there are more contextures or logics to be taken into account, moderating the influence of the financial logic. There are different forms of economization (Caliskan/Callon 2010), of which financialization is only one (e.g., Chiapello 2016: 15; Kädtler 2011). When faced with 'technical' and other 'institutional' environments such as 
customers, the "critical public", or other stakeholders, the financial logic is not sufficient as an orientation for action. It has to be related to other contextures or logics, enabling organizationally different arrangements of these contextures, what can be called ambiguity tolerance or management (Weick 1995), enabling the companies to handle heterogeneous potentially contradictory references to important environments(e.g., Eisenberg 1984; Padgett/Powell 2013): "to gain room for maneuver, actors courtand even create ambiguity. They measure in multiple units, they speak in many tongues" (Stark 2001: 99). In company 8, for example, a differentiated management of these environments was practiced, allowing a partial decoupling of 'talk' and 'action' at different organizational boundaries (Brunsson 1989). In company 5, an overarching strategy was more dominant, with boundary objects as compromising devices, while still stressing the importance of the financial logic.

Considering the overall importance of financialization whilst taking into account the different solutions developed, one could suggest to speak of a financial finalization of sustainability, i.e. of the decisions referring to sustainability: financialization provides an 'external purpose' (Schimank/Volkmann 2012: 170, own translation), making orientation and coordination in decision situations possible. It can then be used as a resource to push sustainability, creating understanding, awareness, and consensus in decision situations. It serves, as seen above, as a legitimatory and orientational device in decision situations, by creating a consequential fiction of consensus by means of commensuration; externally, it serves the construction of unity and actorhood in talk such as reporting, making the organization accountable (Bromley/Sharkey 2015). In decision situations or corporate talk, financialization provides the organization with a functional representation or fiction of a unit whilst operationally unity and integration are not possible or fragile.This is the problem financialization is a solution for - which in turn produces a new problem: despite financialization, in publicly listed companies other contextures have to be taken into account (e.g., Faust 2011; Kädtler 2011; Stout 2012; Froud et al. 2006) whenever sustainability is translated into specific organizational contexts and levels. Operationally, financialization is an insufficient orientation for decisions. Thus, the introduction of sustainability requires forms of ambiguity management which in turn provide further opportunities and restrictions for sustainability.

\subsection{Personalization and the Role of Managers}

The different arrangements of logics and orientations in the companies were further enriched by the role of the perspective of organizational members and managers in particular. Another important contexture constituting the management arrangements within the firms then are the different ways of attributing competences for sustainability and for its internal organizing process, hence the different ways of attributing and assuming agency for sustainability (and its management) within the firm what we will term personalization.

What was most striking in almost all interviews, was the kind of informal identity ascriptions many incumbents of sustainability management (or equivalent, such as environmental management) had to deal with. They have to practice identity work (Ghadiri et al 2015), namely creating and maintaining a socially accepted identity position within the company in relation to other management positions.One recurring category how sustainability managers in companies most often referred to was that of the "tree-hugger". Most of the time, this was evoked when talking about formal decision situations where future possible developments were discussed. One manager, for example, talks about it as creating a "sense of urgency" within the company by referring to market data:

„I check the market data, put them on the table and say: Well, it may not be relevant for you today, but in half a year or in one or two years it will be. This is how it is. That's the state of the art. We can help you with a product where we can guarantee you the sustainable purchase of palm oil. That's certificated, they talk about Round Table for Sustainable Palmoil Production.(...) But I really need to condense market data to create a sense of urgency and this appreciation that the people see: As okay, that makes sense.Because the risk is high to labelled as a treehugger.As the one with the burlap bag."(Company 5, Sustainability; own translation)

The manager first refers to his internal role of creating a sense of urgency by referring to standardized and formalized "market data" which he indeed uses as a resource in order to promote sustainability topics in the company. He then assumes the role of a boundary spanner (Luhmann 1964), translating issues from the organizational environment into the forms compatible inside the company (see 
above).At the same time, with this practice he tries to secure his informally ascribed identity position as amanager with a stable and accepted social (intra-organizational) identity which seems to be precarious, marked by the negative horizon of the "tree-hugger", while other managers in other companies talked about being addressed as "philanthropists". He then uses his formally assigned competences and tasks to address and to counter informal routines, such as the identity ascription which in turn influence agency in formal decision situations. This also implies denying ascriptions of being idealistic in favour of the identity position of a future and change-oriented manager, offering reflective potential to the company (Krichevsky 2014; Tams/Marshall 2011; Ghadiri et al. 2011). Such identity work even permeates into the manager's private life:

I think I also experience that with my friends.Alright, if I tell them what I do then you are the one separating the garbage, the one who goes shopping with a burlap bag. Und then I try to clarify what we stand for here, what we would like to do is always shaped by the interest of creating surplus value for business. But the question is: Does this definition of value in the sense of EBIT persist over the next five or ten years? Or do we have to undergo a transformative process where surplues value needs to be defined much broader?"(Company 5, Sustainability; own translation)

The manager, as in other companies as well, considers himself as part of a "transformative process" which inherently implies countering informal routines and values or organizational cultures. The latter are by definition not malleable by formal decisions, but part of long-term organizational 'evolution' (Luhmann 2011). The sustainability managers try to influence the undecidable, i.e. routines and cultures, by means of formally decided structures and positions, i.e. by exploiting the formal competences assigned to their position to carry out "persuasion work" as he puts it later.In this practice, the manager also needs to mediate between self and external expectations while still having to clearly communicate the company's economic interests: "create added value for business". In company 2, a managers describes his ability to speak different "languages" within his company and explicitly accepts his role of the „bridge builder“:

SUS: (...) I have changed positions many times, because I always felt bored. Well that means that I can speak the customers' language but I can can also speak with a developer. I can do both

I: So, you are a bridge builder.

SUS: Bridge builder, well I can't communiate well because I can get impatient very often when the people

\section{I: Can't follow}

SUS: Don't want to understand. But I just know, I can speak the business language. I always speak about value creation. I never speak about IT, because that's where there is a friction for both of us. Not between both of us, but the way the company positions itself and with what kind of rubbish we present ourselves. I mean that we believe It is everything. It is nothing. IT is enables you, but if I don't explain to the company what she can do with IT (Company 2, Sustainability (SUS); own translation)

Just as the manager in company 5, the manager in company 2 describes his role as mediator between different logics inside and outside the company, promoting corporate sustainability while still reflecting the company's formal purposes and identity. Again, as a representative of sustainability, he makes use sustainability "topics" to make visible what he sees as organizational maldevelopments, trying to rationalize them as changeable while marking the status quo as "rubbish". At the same time, he underlines it as his own competence to initiate change.

In another company, other management positions claim to assume the task of the sustainability management after having described the latter's limited influence earlier in the interview. Again, the reference to organizational decision routines is made to which the management control department try to form a contrast to:

„At least we as management control - well don't misunderstand me that I want to present ourselves in a favourable light while and other in a rather unfavourable - but I can say that we try to assess things very holistically and we also presume to say when we see aspects that we invest in countries where humans are sentenced under sharia law, where there are massive human rights problems, we try to 
make adequate remarks. This happens indeed and I know a lot of colleagues from management control who support it massively. Just to tell you a little anecdote: in the recent board meeting, when we talked about Saudi Arabia, one board member said: „Yes, I am also pro, never ever invest in countries with death sentence." And then he thought about it again - oh, we are also invested in the US. "So, death sentence because of sharia.“"“(Company 4, Management Control; own translation).

By underlining a "holistic" approach, he refers to the values, competences and influence attributable to the "management control colleagues", implicitly contrasting it to different perspectives and thus dissent among the board members even in cases of "massive human rights problems". With his "holistic" approach, however, he seems to be able to disrupt the board's routines from time to time. At the same time, he highlights the complexity and thus the precarious decidability of such decision issues in his "anecdote", where contradictions are re-introduced into the commitment which in turn necessitate exceptions when an economic issue (investment location USA) is provoked.

In general, the management of sustainability is being displaced at the levels of different organizational departments and members - this also implies that the definitions concerning what is at stake in a concrete sustainability related decision situation and hence the handling of different logics is left to organizational members to decide. They are addressed as persons who are to be able to make decisions that also account for sustainability or values in general. In other words, the task of sustainability management is to activate other members to act in the sense of sustainability and the company's economic interests at the same time. Members or departments are then 'responsibilized' (Schamir 2008; Siltaoja et al. 2015), i.e. 'expecting and assuming the reflexive moral capacities of various social actors' (Shamir 2008: 7). In the following passage this 'morality'bears connotations to sustainability as well as economic concepts:

„So, we also believe that a sustainability department is good but our role is to start initiatives. We are happy about each initiative that is not ours, okay? We have vaccinated the people so much, got on their nerves that they say tothemselves: We will do something about it. That's better than the sustainability department saying: You have to do something. And we believe that responsibility for these topics lies in the lines of business. It has to be the product development's responsibility that the products support the customers' sustainability activities or that they are sustainable themselves. So one direction is enablement by the solution, namely not classic sustainability solutions and product safety but it's about installing sustainability criteria into transport, I mean $\mathrm{CO} 2$, energy in transport. Or water in production planning. Orto install human rights, child labour, water, $\mathrm{CO} 2$ footprint into supply chain solutions, alright?That's our core competence.“ (Company 2, Sustainability; own translation)

To sum up, the handling of heterogeneous, incomplementary logics in many companies is also attributed to the reflexive competences of various persons inside the organization (personalization). The sustainability management (or equivalent) positions played a special role here in providing reflective, mediating but also critical capacities to organizational decision processes; the effectivity of this role, however, also seemed to depend on its relative position of influence inside the organization. In general, also other managers seem to attribute or are attributed such reflective capacities. Assuming this role however, always also meant to account for the plurality of potentially incomplementary perspectives and logicswhich surface in organizational decisions, constituting a high complexity of each decision issue. Introducing sustainability into the organization (and into the interview) also meant reflecting about the complex, intricate nature of the decision issues referred to whose direction could however be influenced by the commitments attributable to the personal competences and values of managers. The problem the practice of personalization refers to is then the complexity and, in principle, undecidability of (present and future) organizational cultures and routinesinfluencing decision situations -which nevertheless require a decision (e.g., Groddeck et al. 2015; Andersen 2003). Personalization in its different forms is then a viable solution to this problem: individual managers offer their reflective capacities and competences (in relation to others) to the organization, by being stable points of attribution and identification within the organization that actively irritate organizational routines or that can be referred to and consulted in decision situations. At the same time, as personalizations, these practices always signal their perspectivity and volatility, hence their contingency, being activated temporally without offering stable and obligatory reference points. Loose couplings in the organization between positions, departments or processes are maintained (Orton/Weick 1990). In other words, personalizations keep the organization flexible in view of 
increasingly complex decision issues (Groddeck et al. 2015: 182-184; Andersen 2003) - a complexity also amplified by the introduction of corporate sustainability management and strategies (Christensen et al. 2013).

\section{CONCLuSion}

The ambiguous 'spirit' of contemporary capitalism - Sustainability as an alternative within or to capitalism?

Reconstructing the arrangements of managing incomplementarity in companies brought a complex picture of how the financial logic and the sustainability logic were handled. Table 1 summarizes our findings with respect to the reconstructed specific organizational problems the organizational practices referred to; each in turn we assigned to the two general challenges posed by the rationales of capitalism proposed by Pohlmann (Pohlmann 2014; Pohlmann/Lim 2014); a summary of the effects of the practices for corporate sustainability was added.

With respect to the spirit of capitalism shaping organizational responses to an upcoming institutionalizing sustainability logic potentially creating incomplementarity (question 2), we firstly can state that there is a clear tendency to what can be interpreted as a financialization of sustainability in the sense of a dominant economic action rationale and as a rationale of organizational action (leadership). Is serves as a primary (re-) source of orientation of organizational decision makers and of legitimation towards (relevant) internal and external audiences of organizational investment decisions, i.e. communication and portrayal of such decisions vis a vis and by the board. In this sense, sustainability is finalized by the financial logic. However, when entering operational processes, this finalizing role of the financial logic (co-) produces further problems because of its insufficient capacity to guide the actions of operational units.

Table1. Summary of practices as solutions to specific economic problems and their effects

\begin{tabular}{|c|c|c|c|}
\hline $\begin{array}{l}\text { Practice } \\
\text { (solution) }\end{array}$ & $\begin{array}{l}\begin{array}{l}\text { General challenge } \\
\text { capitalist }\end{array} \begin{array}{c}\text { of } \\
\text { rationales } \\
\text { (cf. }\end{array} \\
\text { Pohlmann/Lim 2014: 4) }\end{array}$ & $\begin{array}{l}\text { Specific problem of } \\
\text { incomplementarity }\end{array}$ & $\begin{array}{l}\text { Effects of practices for } \\
\text { (corporate) sustainability }\end{array}$ \\
\hline $\begin{array}{l}\text { Financialization } \\
\text { (financial } \\
\text { finalization) }\end{array}$ & $\begin{array}{l}\text { "How shall I act in a } \\
\text { specific economic setting?" } \\
\text { (economic action) } \\
\text { "How shall I lead the } \\
\text { company and the } \\
\text { employees?" }\end{array}$ & $\begin{array}{l}\text { - Orientational and } \\
\text { legitimatory problems } \\
-\quad \text { Internal and } \\
\text { external representation of } \\
\text { the impossible unit of the } \\
\text { organization }\end{array}$ & $\begin{array}{llr}\text { - } & \text { Selectivity of } \\
\text { aspects } & \\
- & \text { Problem-fixed } \\
\text { reactivity } & \\
- & \text { Visibility and } \\
\text { 'resonance' for sustainability }\end{array}$ \\
\hline $\begin{array}{l}\text { Ambiguity } \\
\text { management }\end{array}$ & $\begin{array}{l}\text { "How shall I act in a } \\
\text { specific economic setting?" } \\
\text { (economic action) }\end{array}$ & $\begin{array}{l}\text { Insufficiency of (here) the } \\
\text { financial logic as single } \\
\text { action orientation }\end{array}$ & $\begin{array}{l}\text { - } \\
-\quad \text { Pelectivity } \\
\text { reactivity } \\
-\quad \text { Visibility and } \\
\text { resonance for sustainability }\end{array}$ \\
\hline Personalization & $\begin{array}{l}\text { "How shall I lead the } \\
\text { company and employees?" } \\
\text { (organizational activities) }\end{array}$ & $\begin{array}{l}\text { Need for decisions in } \\
\text { complex, } \\
\text { undecidable situations }\end{array}$ & $\begin{array}{l}\text { - } \quad \text { (Formalized) } \\
\text { Addresses for sustainability } \\
\text { related decisions } \\
\text { - } \quad \text { Temporal, punctual, } \\
\text { loosely coupled decisions }\end{array}$ \\
\hline
\end{tabular}

Multiple, sometimes contradictory goals and expectations instituted in different horizontal and vertical organizational units need to managed; discursive as well as pragmatic forms of ambiguity management have to be found.In this sense, also in the German case financial orientations of economic action are prevalent. Yet its relation to other economic orientations is non-trivial. Financialization may (still) dominate discursively in the talk or narratives of company leaders and corporate strategies; yet organizations face the (annual) challenge of the corroboration of the financial 'narratives' directed at investors and the 'numbers' which are ascribed the potency of representing the 'objective' results of financialized strategy and leadership (Froud et al. 2006). Internally, financial orientations, such as the rhetoric of shareholder value, also serve as a resource of influence and the implementation of multiple goals (e.g., Kädtler 2011); the concept of shareholder value itself, as one instantiation of financialization, is ambiguous, allowing multiple courses of action and interpretation (Meyer/Höllerer 2016; Faust 2011). Moreover, the forms of ambiguity management we stressed point in the same direction. Companies are embedded into multiple economic as well as societal 
environments that are made relevant in different ways in organizational activities. The managerial orientations and styles that we observed also point to the limits of financialization: rather than being mere agents of principals (shareholders) and executors of measures to increase shareholder value, managers put internal organizational problems and the economic as well as organizational interests of their own company and of other relevant environments in the first place or at least were able to balance different references. At the same time, the ways of responsibilizing organizational members (see above) or personalizing decisions could also be interpreted as neoliberal management technologies (Siltaoja et al. 2015; Shamir 2008), apparently compatible to financial market orientations.To conclude, the (subjective) spirit of capitalism that we could reconstruct on the basis of our empirical findings bears more ambiguity than is usually assumed in the diagnoses of a globally diffusing financialization. Ambiguity here means that the rationales of economic orientations as well as organizational activities (reflecting the 'subjective spirit of capitalism) are shaped multiple, potentially contradictory, mutually conditioning references - such as financial market expectations, market orientations, internal organizational problems, differentiated and complex managerial mindsets and styles. Financial market orientation as well as neoliberal management thinking seem to prevail (e.g., Pohlmann/Lim 2014; Wilmott 2013), also in the German variant of coordinated capitalism, but indeed it seems to be analytically useful to take into account the varieties of capitalism (Hall/Soskice 2001) when investigating the manifestations of financializations (e.g., Faust 2011).

Concerning the consequences of such a rather 'ambiguous' spirit of capitalism for corporate sustainability as a chance to change or as an alternative to capitalism (question 3), an answer should stress ambivalence. On the one hand, both financialization and ambiguity management produce selectivity in which sustainability topics are attended to (and become visible), and which are excluded from the companies' focus, producing blind spots and hence path dependency for further decisions. This also implies the redefinition of such issues as 'business cases', also constituting just another territory of economic action yielding profits, with the meaning of sustainability issues being reduced in complexity and scope (Senge 2015; Hiss 2013). The decision style behind such selective implementations of sustainability measures, especially in relation to relevant environments, often seems to characterized by a short-term, problem-fixed reactivity, only responding to currently upcoming issues from the environment observed as problems to be tackled immediately. The consequences of ambiguity management moreover run the risk of being perceived as a 'fake' or 'hypocrisy', i.e. as insincere commitments from multiple environments, including investors as well as ecological or social stakeholders (e.g., Zuckerman 1999; Brunsson 1989), undermining, among others,relationships of trust or legitimacy to these actors.

The other side are the productive effects this spirit of capitalism can yield for sustainability. Financialization as well as forms of ambiguity management can be used by (sustainability) managers as resources to foster the successive implementation of sustainability measures. Being'performative', financialization and ambiguity management not only foster selectivity but they also create awareness of and attention to the issues and problems brought to the fore by sustainability strategies. Connectivity and a certain responsiveness for sustainability issues in organizational decisions can be created, achieving a partial coupling of sustainability to organizational core activities. Personalization also provides opportunities for the further development of sustainability: the formal establishment of sustainability management positions also seems to support intra-organizational position-takings stressing reflective and potentially critical capacities in the name of sustainability while not giving up internally accepted management styles of mediating and acting in the company's interests. This internalization of critique (Boltanski/Chiapello 2005) or reflection may also, influenced in the longterm by changing patterns of personnel selection and socialization,support the transformation of capitalist spirits towards 'sustainable' capitalism.

Considering the results of our reconstruction of the 'subjective' spirit of capitalism, sustainability may evolve to an alternative 'within' capitalism rather than 'to' capitalism. We concur with the argument made by Kazmi et al. (2015) concerning of corporate responsibility: in view of the observable selectivities in implementing sustainability measures it is perceivable that this kind of capitalism might not foster the kind of sustainability its proponents envisioned (Senge 2015).

\section{REFERENCES}

[1] Andersen, N.A. (2003): The Undecidability of Decision. In: T. Bakken / T. Hernes (eds):Autopoietic Organization Theory. Oslo: Liber Abstrakt, Copenhagen Business School Press, 235-258. 
[2] Banerjee, S. B. (2007): The Good, the Bad and the Ugly. Cheltenham: Edgar Elgar Publishing.

[3] Beckert, J. (2010): Sind Unternehmen sozial verantwortlich? In: Schumann, O. / Brink, A. / Beschorner, T. (eds.): Unternehmensethik. Forschungsperspektiven zur Verhältnisbestimmung von Unternehmen und Gesellschaft. Marburg: Metropolis, 107-122.

[4] Beyer, J. / Hiß, S. / Wielgohs, J. (2007): Unternehmen zwischen Aktionärsinteressen und sozialer Verantwortung. Berliner Debatte Initial 18/4-5, 3-5.

[5] Bohnsack, R. (2003). RekonstruktiveSozialforschung.Einführung in qualitative Methoden.Opladen: Leske + Budrich.

[6] Boltanski, L. / Chiapello, E. (2005): The New Spirit of Capitalism. London: Verso.

[7] Bowker, G. / Star, S. L: (1999): Sorting Things Out. Classification and Its Consequences. Cambridge: MIT Press.

[8] Bromley, P. / Sharkey, A.J. (2015): Casting call: The expansion of actorhood in US firms, 1960-2010. Accounting, Organization and Society 59, 3-20.

[9] Brunsson, N. (1989): The Organization of Hypocrisy: Talk, Decisions and Actions in Organizations. Hoboken: John Wiley \& Sons

[10] Çalışkan, K. / Callon, K. (2010): Economization, part 2: a research programme for the study of markets. Economy \& Society 39, 1-32.

[11] Cheyns, E. (2011): Multi-stakeholder Initiatives for Sustainable Agriculture:Limits of the 'Inclusiveness' Paradigm. In: S. Ponte /J. Vestergaard/P. Gibbon (eds.): Governing through standards:Origins, drivers and limits. London: Palgrave, 318-354.

[12] Chiapello, E. (2013): Capitalism and Its Criticisms. In: P. Du Gay / G. Morgan (eds): New Spirits of

[13] Capitalisms. Oxford: Oxford University Press, 60-82.

[14] Chiapello, E. (2015): Financialisation of Valuation. Human Studies 38, 13-35.

[15] Cho, C.H. / Laine, M. / Roberts, R.W. /Rodrigue, M. (2015): Organized hypocrisy, organizational façades, and sustainability reporting. Accounting, Organizations and Society 40, 78-94.

[16] Christensen, L. T. / Morsing, M. / Thyssen, O. (2013): CSR as aspirational talk. Organization 20, $372-393$.

[17] Crouch, C. (2005): Three meanings of complementarity. Socio-Economic Review 3/2, 359-363.

[18] Davis, G. / Kim, S. (2015): Financialization of the Economy. Annual Review of Sociology 41, $203-221$.

[19] Du Gay, Paul and Glenn Morgan.2013. New Spirits of Capitalism? Crises, Justifications, and Dynamics. Oxford: Oxford University Press.

[20] Eisenberg E.M. (1984) Ambiguity as strategy in organizational communication.Communication Monographs 51: 227-42.

[21] Epstein G. A. (2005): Financialization and the World Economy. Cheltenham, UK: Edward Elgar.

[22] Espeland, W. N. / Sauder, M. (2007): Rankings and reactivity: How public measures recreate social worlds. American Journal of Sociology 113/1, 1-40.

[23] Espeland, W. N. / Stevens, M. L. (1998): Commensuration as a social process. Annual Review of Sociology 24, 313-342.

[24] Faust, M. (2011): The Shareholder Value Concept of the Corporation and Co-Determination in Germany: Unresolved contradictions or reconciliation of institutional logics. In: Lane, C. / Wood, G. T. (eds.): Capitalist Diversity and Diversity within Capitalism. London: Routledge, 150-188.

[25] Friedland R. and Alford R.R. (1991). "Bringing Society Back in: Symbols, Practices, and Institutional Contradictions". In Powell W.W. and DiMaggio P.J. (eds.) The New Institutionalism in Organizational Analysis. University of Chicago Press, Chicago, 232-266.

[26] Froud, J., Sukhdev, J., Leaver, A., Williams, K. (2006): Financialization and Strategy - Narrative and Numbers. London: Routledge.

[27] Ghadiri, D.P. / Gond, J.-P. / Brès, L. (2015): Identity work of corporate social responsibility consultants: Managing discursively the tensions between profit and social responsibility. Discourse\& Communication 9, 593-624.

[28] Groddeck, V. v. / Siri, J. / Mayr, K. (2016): Die Entscheidungsvergessenheit der Organisationsforschung. Plädoyer für eine operative Entscheidungsforschung. Soziale Systeme 20, 167-192.

[29] Haack, P. / Schoeneborn, D. / Wickert, C. (2012): Talkingthe Talk, Moral Entrapment, Creeping Commitment? Exploring Narrative Dynamics in CorporateResponsibility Standardization. Organization Studies 33, 815-845.

[30] Hall, Peter A. and David W. Soskice. 2001. Varieties of capitalism: the institutional foundations of comparative advantage. Oxford: Oxford University Press. 
[31] Heintz, B. (2010): Numerische Differenz. Überlegungen zu einer Soziologie des (quantitativen) Vergleichs. [Numerical Difference. Toward a Sociology of (Quantitative) Comparisons.] Zeitschrift für Soziologie 39/3, 162-181.

[32] Hiss, S. (2013): The Politics of Financialization of Sustainability. Competition and Change 17/3, 234-247.

[33] Jansen, T. / Schlippe, A. v. / Vogd, W. (2015):Contextural Analysis-A Proposal for Reconstructive Social Research in Organisational Contexts.Forum Qualitative Sozialforschung / Forum: Qualitative Social Research 16, Art. 4.

[34] Kädtler, J. (2011): Financialisation of capitalist economies: bargaining on conventional economic rationalities. Historical Social Research 36, 169-191.

[35] Kazmi, A.B. / Leca, B. / Naccache, P. (2015): Is corporate social responsibility a new spirit of capitalism? Organization 23, 1-21.

[36] Knorr Cetina, K. (2012): What is a financial market? Global markets as microinstitutional and posttraditional social forms. In: K. Knorr Cetina / A. Preda (eds.): The Oxford Handbook of the Sociology of Finance. Oxford University Press, 115-133.

[37] Knudsen, M. (2011). Forms of Inattentiveness: The Production of Blindness in the Development of a Technology for the Observation of Quality in Health Services. Organization Studies 32, 963-989.

[38] Kraatz, M. S. / Block, E. S. (2008): Organizational Implications of Institutional Pluralism. In: R. Greenwood / C. Olivier / R. Suddaby / K. Sahlin (eds.): The SAGE Handbook of Organizational Institutionalism. London: SAGE, 243-275.

[39] Krichewsky, D. (2014): The Socially Responsible Company as a Strategic Second-Order Observer: An Indian Case. MPIfG Discussion Paper 14/10. Köln: MPIfG.

[40] Krippner, G.R. (2011): Capitalizing on Crisis: The Political Origins of the Rise of Finance. Cambridge, MA: Harvard University Press.

[41] Lafaye, C. / Thévenot, T. (2017): An Ecological Justification? Conflicts in the Development of Nature. In: C.Cloutier/ J.-P. Gond / B.Leca (eds.): Justification, Evaluation and Critique in the Study of Organizations (Research in the Sociology of Organizations, Volume 52) Emerald Publishing,273- 300.

[42] Lohmann, L. (2009): Toward a different debate in environmental accounting:The cases of carbon and cost-benefit. Accounting, Organizationsand Society 34/3-4, 499-534.

[43] Luhmann, N. (1964): Funktionen und Folgen formaler Organisation. Berlin: Duncker \& Humblot.

[44] Luhmann N. (2011). Organisation und Entscheidung. Springer VS, Wiesbaden.

[45] Mackenzie, D. (2009): Making things the same: Gases, emission rights and the politics of carbon markets. Accounting, Organizations and Society 34, 440-455.

[46] McDonnell, M.-H. / King, B. / Soule, S.A. (2015): A Dynamic Process Model of Private Politics. Activist Targeting and Corporate Receptivity to Social Challenges. American Sociological Review 80/3, 654-678.

[47] Meadows, D. H. / Dennis, L. / Meadows, J. R., et al. (1972): Limits of Growth. New York: Universe Books.

[48] Meyer, R. / Höllerer, M. (2016): Laying a smoke screen: Ambiguity and neutralization as strategic responses to intra-institutional complexity. Strategic Organization 14, 373-406.

[49] Miller, P. / Power, M. (2013): Accounting, Organizing, and Economizing: Connecting Accounting Research and Organization Theory. Academy of Management Annals 7/1, 557-605.

[50] Milne, M. J. / Gray, R. (2013): W(h)ither Ecology? The Triple Bottom Line, the Global Reporting Initiative, and Corporate Sustainability Reporting.Journal of Business Ethics 118/1, 13-29.

[51] Orton, J.D. / Weick, K. E. (1990): Loosely Coupled Systems: A Reconceptualization. The Academy of Management Review 15, 203-223.

[52] Padgett, J. F / Powell, W. W. (2012): The problem of emergence. In: J. F. Padgett / W. W. Powell (eds.): The Emergence of Organizations and Markets. Princeton: Princeton University Press, 1-29.

[53] Pohlmann, M. (2014): Der Geist des Kapitalismus und seine Trägerschichten. In: P. Hessinger / M. Pohlmann (eds.): Globalisierung als Autokapitalismus? Prüfstandberichte zum Zustand eines Entwicklungsmodells. Wiesbaden: VS.

[54] Pohlmann, M. / Lim, H.-C. (2014): A New "Spirit" of Capitalism? - Globalization and its Impact on the Diffusion of Neoliberal Management Thinking in Germany and the East Asian Economies. Development and Society, 43, 1-32.we

[55] Porter, T. M. (1996): Trust in Numbers.The Pursuit of Objectivity in Science and Public Life.Princeton University Press.

[56] Sahlin, K. / Wedlin, L. (2008): Circulating Ideas: Imitation, Translation and Editing. In: R. Greenwood / C. Olivier / R. Suddaby / K. Sahlin (eds.): The SAGE Handbook of Organizational Institutionalism. London: SAGE, 218-242. 
[57] Schimank, U. / Volkmann, U. (2012): Die Ware Wissenschaft: Die fremdreferentiell finalisierte wirtschaftliche Rationalität von Wissenschaftsverlagen. In: A. Engels / L. Knoll (eds.): Wirtschaftliche Rationalität. Soziologische Perspektiven.Wiesbaden: VS, 165-183.

[58] Seidl D. and Becker K. H. (2006). "Organizations as distinction generating and processing Systems: NiklasLuhmann's contribution to organization studies”. Organization, 13, 9-35.

[59] Senge, K. (2015): Zur Translation und Finanzialisierung von Corporate Social Responsibility. Graf, A. I Möller, Ch. (eds.): Bildung, Macht, Eliten. Frankfurt/M.: Campus, 266-286.

[60] Senge, K. (2007): Ist Corporate Social Responsibility ein ökonomischer Wert? Berliner Debatte Initial 4/5, 47-55.

[61] Shamir R (2008) The age of responsibilization: On market-embedded morality. Economy and Society 37(1): 1-19.

[62] Sillince, J. / Jarzabkowski, P. / Shaw, D. (2012): Shaping strategic action through the rhetorical constructionand exploitation of ambiguity. Organization Science 23, 630-650.

[63] Siltaoja, M. / Malin, V. / Pyykkonen, M. (2015): 'We are all responsible now'. Governmentality and responsibilized subjects in corporate social responsibility. In: Management Learning 46 (4), S. 444-460.

[64] Stark, D. (2001) Ambiguous assets for uncertain environments: Heterarchy in postsocialist firms. In: DiMaggioP.J. (ed.): The Twenty-First-Century Firm: Changing Economic Organization in International Perspective.Princeton, NJ: Princeton University Press, 69-104.

[65] Stout, L.A. (2012): The Problem of Corporate Purpose. Issues in Governance Studies 48, 1-14.

[66] Streeck, W. (2009): Re-Forming Capitalism: Institutional Change in the German Political Economy. Oxford University Press.

[67] Tams, S. / Marshall, J. (2011): Responsible careers: systemic reflexivity in shifting landscapes. Human Relations 64, 109-131.

[68] Thévenot, L. (2001): Organized Complexity Conventions of Coordination and the Composition of Economic Arrangements. European Journal of Social Theory 4, 405-425.

[69] Thévenot L. (2007). "The Plurality of Cognitive Formats and Engagements.Moving between the Familiar and the Public".European Journal of Social Theory, 10, 409-23.

[70] Thompson, J.D. (1967): Organizations in Action: Social Science Bases of Administrative Theory. New Brunswick/London: Transaction Publishers.

[71] Thornton, P. / Ocasio, W. (2008): Institutional logics. In: Greenwood, R. / Oliver, C. / Sahlin, K. / Suddaby, R. (eds.): The Sage Handbook of Organizational Institutionalism. Los Angeles: Sage, 78-98.

[72] Vogd, W. / Feißt, M. / Molzberger, K. / Ostermann, A. / Slotta, J. (2018): Entscheidungsfindungim Krankenhausmanagement. Zwischen gesellschaftlichemAnspruch, ökonomischen Kalkülenund professionellen Rationalitäten. Wiesbaden: VS.

[73] Weber, M. (1989): GesammelteAufsätzezurReligionssoziologie I (Collected Essays on the Sociology of Religion I). Tübingen: Mohr.

[74] Weick, K. E. (1995): Sensemaking in Organizations. Thousand Oaks: Sage.

[75] Werron, T. (2014): On public forms of competition. Cultural Studies - Critical Methodologies 14/1, 62-76.

[76] White, H. C. (1981): Where do Markets Come from? American Journal of Sociology 87, 517-547.

[77] Willmott, H. (2013): Spirited Away: When Political Economy Becomes Culturalized. In: P. Du Gay / G. Morgan (eds.): New Spirits of Capitalism? Crises, Justifications, and Dynamics. Oxford: Oxford University Press, 98-123.

[78] Windolf, P. (ed.) (2005): Finanzmarkt-Kapitalismus. Analysen zum Wandel von Produktionsregimen. Kölner Zeitschrift für Soziologie und Sozialpsychologie. Sonderband 40. Wiesbaden: VS.

[79] Zuckerman, E.W. (1999): The categorical imperative: Securities analystsandtheillegitimacydiscount. AmericanJournal of Sociology 104, 1398-1438.

Citation: Konstanze Senge (Prof.), Simon Dabrowski (M.A.). "Alternatives Within Capitalism: Sustainability, Financialization, and the Ambiguity of Contemporary Capitalism" International Journal of Humanities Social Sciences and Education (IJHSSE), vol 7, no. 7, 2020, pp. 171-188. doi: http://dx.doi.org/10.20431/23490381.0707020 .

Copyright: (C) 2020 Authors. This is an open-access article distributed under the terms of the Creative Commons Attribution License, which permits unrestricted use, distribution, and reproduction in any medium, provided the original author and source are credited. 